of all legs. The tarsi are divided into two parts by a transverse suture ; posterior pairs of legs but little larger than the anterior pairs.

Washington State. [Kincaid.] Two specimens.

Chthonius spinosus, n. sp.

Length, I.7 mm. Colour, hard parts pale tinged with reddish-brown, venter of abdomen white; abdomen with a few silvery white spots. Anterior part of cephalothorax a little wider than posterior, the anterior portion bent downward and divided in the middle by a deep furrow, the mandibles bent downward; the cephalothorax, basal joints of mandibles, and segments of abdomen provided with scattered conical tubercles which bear a spine at tip. Cephalothorax and palpi finely granulated, basal joint of palpus [trochanter] short, not visible from above ; femur about length of cephalothorax, sides nearly straight, tip a little larger than base, patella short, almost conical; hand once and a-half as long as patella, sides nearly straight but little swollen, the inner side the most so; fingers straight, longer than hand. Eyes a little more than their diameters apart. Abdomen twice as long as cephalothorax. Anterior legs long and slender; posterior pairs larger but hardiy longer; trochanters distinct on posterior pairs.

Citrus Co., Florida. [C. M. Weed.] Quite common.

DESCRIPTIONS OF NEW BRACONIDS BRED BY PROF. A. D. HOPKINS.

By William H. AShmead, WAShington, D. C.

In the following pages I describe the new Braconids bred by Prof. A. D. Hopkins, of the West Virginia Agricultural Experiment Station, as recorded by him in Insect Life, Vol. IV., pages $25^{6}$ to 259 .

The types are in the National Museum.

\title{
Subfamily BRACONIDÆ.
}

BraCON, Fabr.

(1) B. lixi, sp. n. Bracon lixi, Ashm., MS., Ins. Life, IV., p. 257.

q-Length, $3.5 \mathrm{~mm}$. ; ovipositor, I mm. Brownish-yellow; stemmaticum, metathorax above, first abdominal segment and an oblong median spot on second segment at base, black; sometimes the middle lobe of meso-scutum is black anteriorly; antennæ 35 -jointed, brown. Head and thorax smooth, shining, the head transverse. Wings hyaline ; tegulæ yellow ; costa, stigma and nervures dark brown; recurrent nervure 
received in the apical angle of the first submarginal cell; second abscissa of radius twice as long as first ; second submarginal cell twice as wide at base as at apex. Legs pale brownish-yellow, the apex of posterior tibiæ above and the basal 3 or 4 joints of tarsi more or less dusky. Abdomen oblong oval, the first segment above and the black median spot on the second, rugulose ; rest of the surface granulated or shagreened ; the first segment is the longest; the second and third about equal, the suture between being distinct, crenated; the following subequal, the fourth being one-third shorter than the third.

Hab.-Morgantown, W. Va.

Bred from Lixus scrobicollis, living in Ambrosia trifida.

(2) B. rufomarginatus, sp. n.

q-Length, $2 \mathrm{~mm}$; ovipositor, $0.5 \mathrm{~mm}$. Polished black; orbits, a line extending from base of eye and along the clypeus, yellow; palpi black; legs black, beneath pale brownish; lateral margins of the abdomen and the venter reddish-yellow; antennæ 24 -jointed, black; wings fuliginous; the second abscissa of radius one-half longer than the first; the second submarginal cell not narrowed at apex.

Hab.-Morgantown, W. Va.

Comes nearest to $B$. phycidis Riley, but with darker wings and different coloured legs.

\section{Subfamily EхотнесіNÆ.}

Rhysipolis, Forster.

(3) ? R. biformis, sp. n. Rhysipolis biformis, Ashm., MS., Ins. Life, IV., p. 257 .

o -Length, $3.5 \mathrm{~mm}$; ovipositor a little longer than the abdomen. Head and thorax black, pubescent ; abdomen ferruginous ; anterior coxæ, all trochanters, except slightly on the upper surface, annulus at base of all tibiæ and all tarsi, honey-yellow or pale ferruginous; middle and anterior coxæ and all femora black; mesopleura reddish or piceous. Head quadrate, above smooth, polished, with a delicate occipital margin ; face finely punctate with a sparse, rather long, whitish pubescence ; mandibles black; palpi piceous. Thorax finely shagreened, the parapsidal furrows obsolete posteriorly but sharply defined anteriorly, the middle lobe just in front of scutellum depressed, rugulose with a slight median keel ; meso-pleura smooth and pale or piceous at the middle, with a slight longitudinal sulcus; scutellum smooth, with a crenate furrow across the base; meta-thorax rugose, with a delicate median carina down the centre 
slightly forked at apex. Wings subfuliginous, the stigma and venation brown; submedian cell longer than the median, the recurrent nervure not interstitial but joining the first submarginal cell at the lower apical angle; first abscissa of radius about half the length of the second. Abdomen ferruginous or reddish-yellow; the first and second segments rugose or shagreened, the following smooth, polished. In one specimen the basal part of the third segment, as well as the first two, is also shagreened.

In the of the apical margins of the third and following abdominal segments are piceous; the antennæ are much longer than the body, brown-black, 36-jointed; the legs similar to the female, but with the femora more piceous, not black; otherwise as in female.

Hab.-Morgantown, W. Va.

Bred Sept. I 4 , I 891 , from a Buprestid, or Longicorn, larva living under bark of dead Spruce Abies nigra.

I am doubtful about the position of this insect, as it might just as well be placed in the genus Doryctes as in Rhysipolis, having a close resemblance to Doryctes radiatus Cr., D. macilentus Prov., D. fartus Prov., and other species in this genus.

\section{Subfamily RhysSALiNÆ.}

Rhyssalus, Haliday.

(4) R. pityophthori, sp. n. Rhyssalus pityophthori, Ashm., MS., Ins. Life, IV., p. 257.

o-Length, I. 2 mm.; ovipositor shorter than the abdomen. Black, shining; head transverse, smooth, impunctured; mandibles and palpi pale ferruginous ; antennæ very little longer than the body, (?) I 7 -jointed. Thorax alutaceous, the parapsidal furrows distinct, the middle lobe with a median impressed line anteriorly. Wings hyaline, strongly iridescent, the stigma and nervures brown, the first abscissa of radius two-thirds the length of the second, the marginal cell long, extending to tip of wing. Legs, including coxæ, pale or honey-yellow. Abdomen oblong-oval, ferruginous, the ovipositor black.

Hab.-Morgantown, W. Va.

Bred July 29, I89I, from Yellow Pine twigs infested with Pityophthorus, sp. 


\section{Subfamily SPathine. \\ Spathius, Nees.}

The following table will aid in determining the species in this genus known to me as occurring in our fauna :-

\section{TABLE OF SPECIES.}

Wings fuscous or blackish, with 3 white transverse bands (i.e., one white

band with the base and apex of wing white) $\ldots \ldots \ldots \ldots \ldots \ldots \cdots$

Wings fuscous, with one white band $\ldots \ldots \ldots \ldots \ldots \ldots \ldots$

Wings hyaline or subhyaline, without bands.

Testaceous; pleura, metathorax and petiole blackish or fuscous.

Petiole very long and slender, two-thirds the length of the thorax ; legs entirely pale yellow; antennæ 24 -jointed. ( $\delta$, length, 2.5 to $3 \mathrm{~mm}$.) .......... longipetiolatus, sp. n.

Testaceous; abdomen from apex of second segment black.

Petiole not more than half the length of thorax; legs pale yellow ; antennæ 24 -jointed. (ot, length, $2.1 \mathrm{~mm}$.)...... .S. californicus, sp. $\mathrm{n}$.

Black; face, collar, mesopectus, legs, petiole and basal half of second abdominal segment, testaceous.

Petiole a little longer than half the length of thorax; hind femora subfuscous. Antennæ 23 -jointed. ( $\hat{3}$, length, $2 \mathrm{~mm}$.)

2. Black; head, apex of petiole, base of second segment, fuscous or piceous; all femora much swollen; trochanters, annulus at base of tibiæ and the tarsi, white; ovipositor twice the length of abdomen. Antennæ 34 -jointed. ( $q$, length, 4 to $4.5 \mathrm{~mm}$.)..S. unifasciatus,sp.n.

3. Species for the most part testaceous or brownish-yellow $\ldots \ldots \cdots 4$ Species black or dark fuscous.

Collar, petiole and base of second segment, pale brownish-yellow ; trochanters, base of tibiæ and the tarsi, yellowish-white; sometimes the mesopectus and head more or less rufo-testaceous; basal half of second abdominal segment always finely sculptured or shagreened; ovipositor $\mathrm{I} / 2$ to 2 times as long as the abdomen.

$q$, antennæ 32 to 35 -jointed; of, antennæ 25 -jointed. (Length, from 2 to $4.5 \mathrm{~mm}$.).......S. simillimus, $\mathrm{sp} \mathrm{n}$. 
Ovipositor not longer than the abdomen.

Head polished, with traces of faint transverse striæ before the ocelli but none behind; second abdominal segment faintly granulated at base.

q, antennæ $29-30$; $\hat{\delta}, 26$-jointed. (Length, 2 to 2.5 $\mathrm{mm}.) \ldots \ldots \ldots \ldots \ldots \ldots$. . tomici, sp. n.

Ovipositor half the length of abdomen.

Head transversely rugulose; second abdominal segment perfectly smooth, polished.

q, antennæ broken. (Length, $3 \mathrm{~mm}$.)..........

.................... brachyurus, sp. n.

4. Rust brown, disk of thorax and scutellum black.

Ovipositor nearly twice the length of the whole insect.

Head polished, although faintly transversely aciculated; abdomen elongate, black, shining, the petiole finely rugose, not longitudinally striated; the second segment with some faint aciculations only at base.

$q$, antennæ 20 -jointed, reaching only to the base of the metathorax. (Length 3.5 to $4 \mathrm{~mm}$.).........

Ovipositor not quite as long as the whole insect.

S. Laflammei, Prov.

Head opaque, finely rugose, the rugæ posteriorly transverse; abdomen oblong-oval, the apical one-third of the second segment and following segments black polished; petiole coarsely longitudinally striated; basal half of second segment shagreened.

, antennæ multiarticulate (broken at tips). (Length, $5.5 \mathrm{~mm}$.).............. floridanus, sp. n.

Brownish-yellow or testaceous, sometimes varied with fuscous.

Ovipositor shorter than the body, usually shorter than the abdomen.

Heàd finely rugose and transversely aciculated; second abdominal segment basally feebly shagreened; ovipositor longer than the abdomen. (Length, 4.5 to 5 mm.) ................ trifasciatus, Riley.

Ovipositor shorter than abdomen.

Head polished without or with very faint transverse aciculations; base of second segment and the petiole yellow, 
rest of abdomen black, the basal half of the second segment very finely shagreened. Antennæ 23 -jointed, a little longer than the body. ( $q$, length, $2.8 \mathrm{~mm}$.).. .......................... Canadensis, Ashm. Head shining, transversely striated; basal two-thirds of second segment finely shagreened, the rest of abdomen smooth, polished. Antennæ 30-jointed, longer than the body. ( $q$, length, $3.5 \mathrm{~mm}$.)........S. pallidus, sp. n. Head opaque, minutely transversely rugulose; the second segment has the basal one-third finely shagreened, then followed by a smooth polished space and again shagreened, and polished again at apex. Antennæ longer than the body, more than 33 -jointed (the tips broken off). ( $q$, length, $4 \mathrm{~mm}.) \ldots \ldots \quad \ldots$. . brunneus, Ashm. Head smooth polished, with scarcely a trace of any transverse aciculations; second segment polished, impunctured. Antennæ 25-jointed. ( $q$, length, $3 \mathrm{~mm}$.)..... $\ldots \ldots \ldots \ldots \ldots \ldots \ldots \ldots \ldots \ldots \ldots \ldots$ sequoice, Ashm.

(5) S. claripennis, sp. n. Spathius clavipennis, Ashm., MS. (err. impr.), Ins. Life, IV., p. 257.

ई.-Length, $2 \mathrm{~mm}$. Black; prothorax, mesopectus, petiole and basal half of second abdominal segment, testaceous or yellow ; legs pale, the posterior femora and their tibiæ toward apex slightly dusky. Wings hyaline, the stigma and nervures brown. Antennæ 23-jointed, fuscous, the basal three or four joints pale yellowish. The head is polished, with some faint transverse aciculations on the vertex. Thorax subopaque, finely granulated or shagreened; the petiole longitudinally striate.

Hab.-Morgantown, W. Va.

Bred April 20, 1892 , from Polygraphus rufipennis living under the bark of dead Abies nigra.

(6) S. unifasciatus, sp. n. 'Spathius unifasciatus, Ashm., MS., Ins. Life, IV., p. $25^{8}$.

9.- - Length, 4 to $4.5 \mathrm{~mm}$. Black ; collar anteriorly dull ferruginous ; apex of petiole and base of second segment reddish piceous; legs fuscous, anterior and middle coxæ and trochanters, posterior trochanters and annulus at base of all tibiæ, white; tarsi more or less pallid beneath. Antennæ 34 -jointed, fuscous, the basal 3 or 4 joints pallid. The head is polished, the vertex faintly transversely aciculated, the frons and 
face rougher; thorax closely granulated, opaque, the middle lobe pos. teriorly, pleura and metathorax, finely rugulose, the latter indistinctly areolated. Wings fuliginous, with a white band across the middle from the base of the stigma, the apex of the wing showing scarcely any white. All the femora are very much swollen, while the abdomen, except the petiole, is smooth, polished; petiole longitudinally striate, somewhat rugose basally.

Hab.-Morgantown, W. Va.

Bred April 29, I892, from Scolytus 4-spinosus living under the bark of Carya alba.

(7) S. simillimus, sp. n.

¿, $q$.- - Length, 2 to $4.5 \mathrm{~mm}$. Black; collar, mesopectus and petiole pale ferruginous or brownish-yellow. Head above transversely aciculated; thorax opaque, closely granulated; the middle mesothoracic lobe posteriorly and the metathorax finely rugose, the latter faintly areolated; petiole striate. Wings fuscous, white at base and tips, and with a transverse white band from the base of stigma. Antennæ in $q 32$ to $35^{-}$ jointed, in of 25 -jointed, fuscous, pale toward base. Legs fuscous ; the coxæ and trochanters, annulus at base of tibiæe and the tarsi, white. Abdomen, except petiole and base of second segment, black, the basal half of the second segment shagreened; ovipositor as long or very little shorter than the body.

Hab.-Morgantown, W. Va.

Bred May i 8 and 25, 1892, from Agrilus bilineatus living in White Oak stump.

(8) S. brachyurus, sp. n. Spathius brevicaudus, Ashm., MS. (Olim. preoc.), Ins. Life, IV., p. 258.

q.-Length, $3 \mathrm{~mm}$; ovipositor half the length of abdomen. Much like $S$. simillimus, but with the lower part of head, the prothorax, metathorax and petiole brownish, the ovipositor very much shorter, in simillimus being about as long as the whole insect, while in brachyurus it is only half the length of the abdomen. The head is transversely rugulose; the legs and antennæ brown, the tibiæ not annulated with white, the femora not especially thickened; while the second abdominal segment is perfectly smooth and polished.

Hab.-Morgantown, W. Va.

Bred Nov. Io, 1890, and March 15, I891, from Dryocoetes autographus living under bark of dead Abies excelsa. 
(9) S. pallidus, sp, n.

9.-Length, $3.5 \mathrm{~mm}$; ovipositor a little longer than the abdomen. Pale ferruginous or honey-yellow ; coxæ, trochanters, base of tibiæ and tarsi, whitish. Head shining, transversely striated; antennæ 30-jointed, longer than the body ; petiole as long as the body of abdomen, striated; second abdominal segment nearly twice the length of the third, the basal two-thirds finely shagreened or coriaceous, the following segments polished, impunctured. Wings fuscous, whitish at base and tips, and with a white band across from base of stigma. The parapsidal furrows are distinct, converging and meeting at base of scutellum, the midd!e lobe thus formed being smooth and not rugose at base just in front of the scutellum, as in the other species.

Hab.-Morgantown, W. Va.

Bred from Tomicus cacographus living in Yellow Pine.

Subfamily Hecabolinæ.

Lysitermus, Förster.

(г) L. scolyticida, sp. n. Lysitermus scolyticida, Ashm., MS., Ins. Life, IV., p. 258.

q.-Length, 2. I mm. Black, shining, impunctured; mesoscutum with two distinct furrows; metathorax finely rugose; wings hyaline, neryures brown; legs honey-yellow, the posterior tibiæ and tarsi subfuscous. Antennæ 17 -jointed, black, the three basal joints yellow. Abdomen oblong-ovate, composed of but three visible segments, the first segment and the second at the extreme base striated, otherwise smooth and polished ; ovipositor as long as the abdomen.

Hab.-Morgantown, W. Va.

Bred April 30, I89 I, from Scolytus 4-spinosus living under Hickory bark.

\section{Cænophanes, Forster.}

In describing the species in this genus reared by Prof. Hopkins, I have taken advantage of the opportunity to publish a table of the species known to me in our fauna, believing the characters given in the table sufficient for the recognition of all the species.

TABLE OF SPECIES.

Testaceous or brownish-yellow species . . . . . . . . . . . Black or blackish-fuscous species.

Ovipositor longer than the whole insect. 
Collar and legs yellow; abdomen piceous ; first segment and basal two-thirds of second longitudinally striated, the second with a transverse impressed line at the middle.

Metathorax with two areas at base; antennæ in $q$ 24-jointed............ longicaudus, sp. n.

Metathorax rugose, but without areas at base ; antennæ in $q \mathrm{r} 8$-jointed....C. flavicollis, sp. $\mathrm{n}$.

Ovipositor not quite as long as the body.

Head piceous, polished; collar, mesosternum, legs and basal half of abdomen, yellow ; antennæ 24 -jointed ; metathorax with two smooth areas at base......C. consimilis, sp. n. Ovipositor scarcely as long as the abdomen.

Head minutely punctulate, subopaque; legs, base of second abdominal segment and the three terminal segments, yellowish; first segment, basal two-thirds of second and base of third and fourth, striated; the second segment with two transverse impressed lines; antennæ 28 -jointed . C. langurice, sp. n.

Head transversely aciculated, shining; legs brown, trochanters and tarsi yellow; abdomen piceous black, the first and second segments striated, the following smooth; antennæ in $q \mathrm{r} 9$, in of $\mathrm{r} 8$-jointed ........... atrata, Ashm.

Ovipositor half the length of abdomen.

Head polished, impunctured; legs yellowish-white; abdomen piceous or yellowish at base of second segment, also sometimes at apex of first; first segment, basal two-thirds of second and base of third, striated; rest of abdomen smooth, shining, the second segment with a transverse impressed line at the middle; antennæ in $q 23$-jointed..

C. anthaxice, sp. n.

Head transversely aciculated; legs brownish-yellow, the hind coxæ black; abdomen finely rugose, the first segment and the following segments (except apical portion of the 3, 4 and 5 , two-thirds of the 6 and the 7 , which are polished), striated; second segment with two longitudinal furrows; antennæ 25 -jointed ............. borealis, Ashm.

Legs pale brown, trochanters and tarsi whitish; abdomen elongate ovate, black, polished, the first two segments and 
the third at extreme base striated, the second segment without a transverse furrow ; $\delta$, antennæ 2 2-jointed..... C. pityophthori, sp. n.

Ovipositor one-third the length of abdomen.

Head smooth, polished; collar, mesosternum, second abdominal segment and the apex of abdomen, more or less, yellow ; first segment, basal two-thirds of second, and base of third and fourth, striated; the second with two transverse impressed lines; antennæ 25 -jointed.......... .C. floridanus, sp. $\mathrm{n}$.

2. Ovipositor longer than the abdomen.

Head black or piceous black, polished, impunctured; scutellum with two large foveæ at base; metathorax with two large areas at base, posteriorly rugose or reticulated; antennæ in $q 3 \mathrm{I}$-jointed ....................... atriceps, sp.

Ovipositor two-thirds the length of abdomen.

Metathorax with two areas at base.

Head transversely aciculated.

First abdominal segment and basal two-thirds of second striated; rest of abdomen smooth, polished, the second segment with a transverse impressed line ; antennæ in $\delta$ and $q 25$-jointed... C. hylotrupidis, sp. n.

First abdominal segment, basal two-thirds of second, and the bases of the third and fourth, striated, the second with two transverse impressed lines; antennæ in $\delta$ 30-, in $q 25$-jointed............ ................... aciculatus, sp. $\mathrm{n}$.

Ovipositor less than half the length of the abdomen.

Metathorax with a petiolate, diamond ( $\left(\begin{array}{l}v \\ )\end{array}\right)$ shaped area.

Head transversely aciculated ; first abdominal segment, the second, except at apex, and base of third and fourth, striated, the second with a transverse impressed line at basal one-third and a transverse depression a little beyond ; antennæ in $q 36$-jointed. .C. prodoxi, Riley. Metathorax rugose, reticulated, with two areas at base.

Head smooth, polished; first abdominal segment, 
basal two-thirds of second, striated, the second with a transverse furrow at the middle.........

Ovipositor one-third the length of abdomen.

Metathorax rugose, but not areolated; first abdominal segment and basal half of seccnd, striated; rest of abdomen smooth, polished; antennæ in $q$ s 8-, in of 19 -jointed.... ....................... Koebelei, Riley.

Metathorax with a petiolate, diamond-shaped area at the middle and with two areas at base ; first, second and base of third abdominal segments striated, the rest smooth, polished; antennæ in $\& 24$-jointed, in $\{27$ or 28 -jointed..........

C. Chittendenii, sp. n.

(го) C. langurice, sp. n. Caenophanes languriæ, Ashm., MS., Ins. Life, IV., p. 258.

o , o .- - Length, 2.5 to $3 \mathrm{~mm}$; ovipositor scarcely as long as the abdomen. Head and thorax black, the parapsidal furrows, collar and mesopleura ferruginous, with sometimes the face and orbits ferruginous, the second abdominal segment with 2 transverse impressed lines; abdomen in $\hat{\delta}$ pale ferruginous, in $q$ darker, with the base of second abdominal segment and the three last segments yellowish. Head minutely punctulate; antennæ in both sexes 28 -jointed; wings sub-hyaline, the first and second branches of the radius equal in length ; first abdominal segment, basal two-thirds of second, and base of the third, and in the $f$ the sutures at base of 3,4 and 5 , striated.

Hab.-Morgantown, W. Va.

Bred Dec. 24, I891, and Feb. 24, 1892, from Languria larvæ living in pith of Ambrosia trifida and artemisicefolia.

( I I) C. anthaxice, sp. n. Caenophanes anthaxiæ, Ashm., MS., Ins. Life, IV., p. 258.

f, $q$.-Length, 2.5 to $3 \mathrm{~mm}$.; ovipositor half the length of abdomen. Head and thorax in $\delta$ black, in $q$ fuscous; the head polished, impunctured; thorax closely microscopically punctate, the middle lobe posteriorly rugose; abdomen ferruginous, the first segment, basal twothirds of the second, and the suture between segments 3 and 4 , striate; legs pale yellow ; wings hyaline, the first abscissa of radius two-thirds the length of the second. Abdomen sometimes fuscous, with a pale blotch at the middle. 
Hab.-Morgantown, W. Va.

Bred May 4 and June 24, I892, from Anthaxia viridicornis infesting Willow; and May 26, from an Agrilus larva living under the bark of Dogwood, Cornus florida.

(1 2) C. pityophthori, sp. n. Caenophanes pityophthori, Ashm. M. S., Ins. Life, IV., p. 258.

t.--Length, $2 \mathrm{~mm}$. Black; second abdominal segment at base and sometimes the petiole at apex ferruginous; head shining, faintly transversely aciculated on vertex ; thorax opaque, minutely granulated ; metathorax areolated, the pleura rugose; antennæ 22 -jointed, black, the 3 basal joints yellow; abdomen elongate ovate, black, polished, the first two segments and the third at extreme base or the suture striated. Legs pale yellowish. Wings hyaline, the first abscissa of radius less than twothirds the length of the second.

Hab.-Morgantown, W. Va.

Bred Feb. 24, I892, from Pityophthorus sp. living under the bark of a small dying Spruce, Abies nigra.

(г) C. hylotrupidis, sp. n. Caenophanes hylotrupidis, Ashm., MS., Ins. Life, IV., p. 258.

f, $q$.- - Length, 2.5 to $3 \mathrm{~mm}$; ovipositor two-thirds the length of abdomen. Pale ferruginous; metathoracic sutures fuscous. Head above transversely aciculated; thorax finely granulated, the middle lobe posteriorly strongly rugose ; metathorax, except the two basal areas, rugose, and with a $\Lambda$-shaped carina at the middle; first abdominal segment and basal two-thirds of the second striate, rest of abdomen smooth, polished, the second segment with a transverse impressed line at the middle. Antennæ in both sexes 25 -jointed. Wings hyaline, the stigma and nervures pale brown, the first and second branches of the radius about equal in length.

Hab.-Morgantown, W. Va.

Bred April 4, I89I, from Hylotrupes ligneus living in Juniperus virginiana.

Subfamily Helconine.

Helcon, Nees.

( 14) H. ocsidentalis, Cr. Helcon tetrapodii, Ashm., MS. (olim), Ins. Life, IV., p. 259.

Bred July 14, I891, from Tetrapodium cinnamoplerum living in sapwood of Spruce log Abies nigra. 


\section{Subfamily Alysine.}

(r5) A. tibialis, sp. n.

Adelura, Förster.

f.-Length, I.5 mm. Polished black; lower half of head, two basal joints of antennæ, legs, including coxæ, except the posterior tibiæ which are fuscous, and first and second abdominal segments, honey-yellow. Head transverse, wider than the thorax, the ocelli close together. Palpi white. Antennæ 24 -jointed, black, much longer than the body. Thorax smooth, without distinct parapsidal furrows, or only indistinctly impressed anteriorly. Mesopleura piceous ; metathorax almost smooth, the surface wrinkled posteriorly. Wings large, hyaline, the tegulæ white, the costa and the elongate stigma black; rest of venation brown; the first branch of the radius very short, the second very long, about twice the length of the first transverse cubital nervure; the second submarginal cell very long, twice as broad at base as at apex ; recurrent nervure almost interstitial received in the angle of the second submarginal cell; submedian cell a little longer than the median. Abdomen oblong-oval, smooth, shining, the first segment finely rugose.

Hab.-Morgantown, W. Va.

\section{Subfamily DacnusenÆ.}

(г6) C. Hopkinsii, sp. n.

Coelinius, Nees.

9.-Length, $4 \mathrm{~mm}$. Black, shining; prothorax, legs, including coxæ, and the second abdominal segment, brownish-yellow ; mandibles rufous ; palpi white. Head oblong, smooth and polished; face punctate with a median carina, pubescent. Antennæ 33-jointed, black, as long as the body; the two basal joints, and the flagellum beneath for more than half its length, brownish-yellow. Thorax smooth, shining, trilobed; mesopleura separated from the mesosternum by a large longitudinal furrow and with a triangular fovea posteriorly; the surface, except anteriorly where it is sparsely punctate, is smooth and shining; metathorax rugose. Wings hyaline, the venation brown-black, the costa towards base and the tegulæ yellowish. Abdomen twice as long as the thorax, compressed beyond the second segment; except the second segment, black, smooth and shining; the first segment is one-third longer than the second, rugulose, smoother at apex.

Hab.-Morgantown, W. Va. 


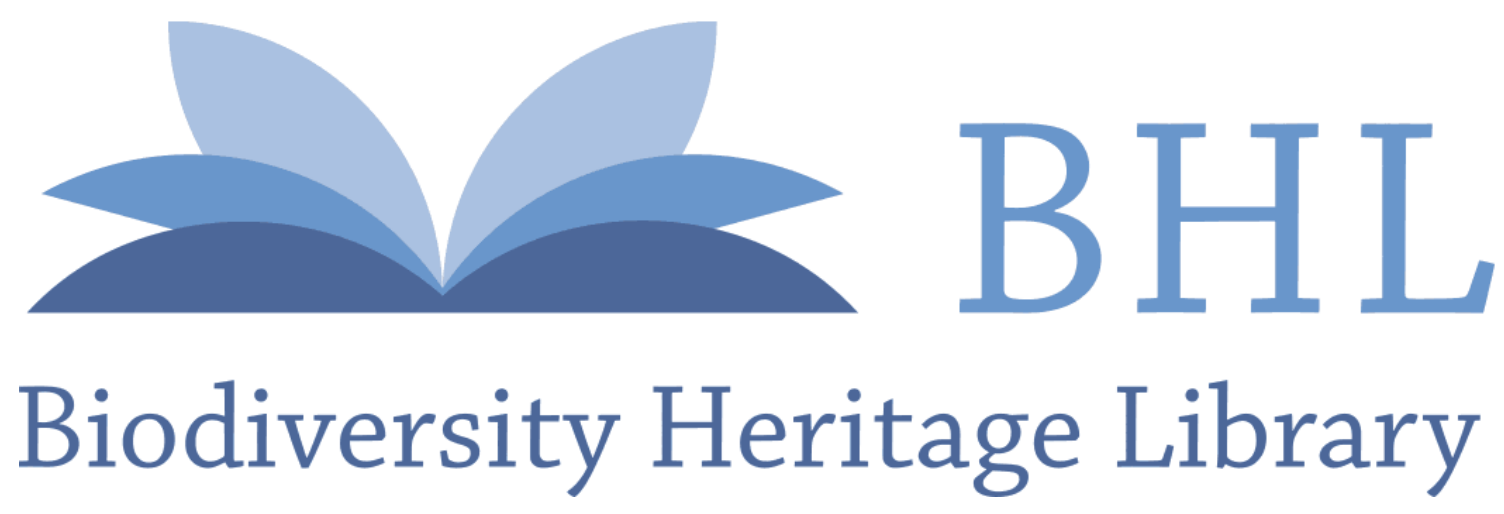

Ashmead, William H. 1893. "Descriptions of new braconids bred by Prof. A.D. Hopkins." The Canadian entomologist 25, 67-79.

https://doi.org/10.4039/Ent2567-3.

View This Item Online: https://www.biodiversitylibrary.org/item/22138

DOI: https://doi.org/10.4039/Ent2567-3

Permalink: https://www.biodiversitylibrary.org/partpdf/19370

\section{Holding Institution}

MBLWHOI Library

Sponsored by

MBLWHOI Library

\section{Copyright \& Reuse}

Copyright Status: NOT_IN_COPYRIGHT

This document was created from content at the Biodiversity Heritage Library, the world's largest open access digital library for biodiversity literature and archives. Visit BHL at https://www.biodiversitylibrary.org. 